\title{
THYBORØN HARBOUR - STUDY OF WAVE AGITATION AND SEDIMENTATION
}

\author{
Sanne L. Niemann ${ }^{1}$ (sln@ dhigroup.com), Peter Sloth ${ }^{1}$ (prs@ dhigroup.com), Jørgen Buhl ${ }^{2}$ (jb@ thyboronport.dk), Rolf \\ Deigaard ${ }^{1}\left(\right.$ rd@dhigroup.com) and Ida Brøker ${ }^{1}$ (ibh@dhigroup.com)
}

Thyborøn Harbour, one of Denmark's busiest fishing ports, has during the recent years experienced increasing challenges by high waves and by sedimentation in the approach to and at the harbour. The causes for these phenomena were far from obvious, and an extensive study was initiated to identify the causes and find possible solutions. The methodology and the results are described in this paper.

Keywords: tidal inlet; sediment transport modelling; wave agitation; wave modelling

\section{INTRODUCTION AND BACKGROUND}

Thyborøn Harbour is situated in the Thyborøn Channel, which is the inlet from the North Sea to the large Limfjord system, which extends all across Jutland to another inlet at the east coast, see Fig. 1. The current in the channel is tidal, but the most important are meteorogically driven flow events in or out of the inland fiord system. The harbour is placed on the western side of the inlet channel at the inshore side of the southern barrier and has been considered well protected from the severe westerly waves attacking the West Coast of Jutland from the North sea. This protected location has been important for the development of the harbour to become one of Denmark's busiest fishing harbours and at the same time a commercial harbour with the third largest turnover in tonnage on the Danish North Sea coast. Increase in the activity and the size of the vessels using the harbour has put emphasis on the navigational depth and the conditions in the harbour with respect to wave disturbance.

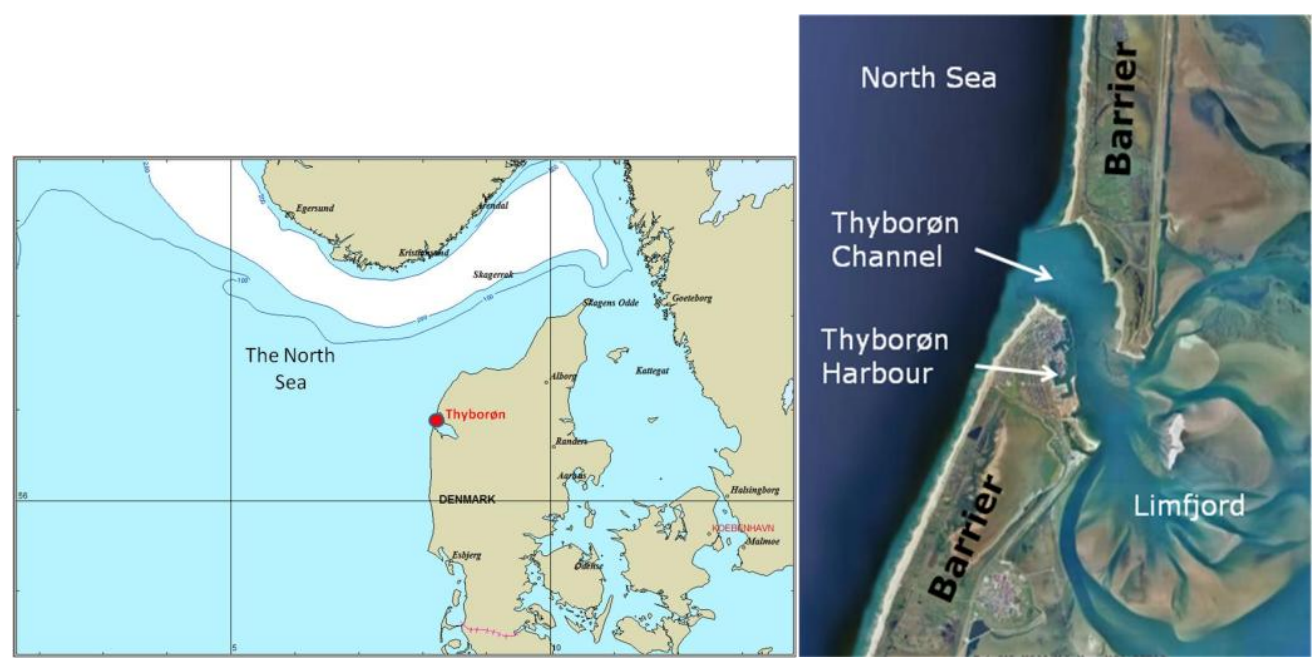

Figure 1. The location of Thyborøn Harbour.

The natural conditions in the area are very dynamic. The present opening of the Limfjord to the North Sea was created in 1862 when the barrier was breached during a severe gale. After the breach large amounts of sand was transported in through the channel to be deposited on shoals in the fjord inside the channel. The channel acted as a major sink of coastal sediment and severe coastal erosion of about $20 \mathrm{~m} / \mathrm{yr}$ occurred on the barriers north and south of the channel. The maximum retreat of the coastline was about $1500 \mathrm{~m}$. To stabilize the coast and protect the town of Thyborøn an extensive construction programme for groynes and flood protection dikes was initiated in the 1870-ies and the construction of the harbour began in 1914 . The groynes have practically maintained the position of the

\footnotetext{
${ }^{1}$ DHI, Agern Allé 5, DK-2970 Horsholm, Denmark

2 Thyborøn Havn, Tankskibsvej 4, DK-7680 Thyborøn, Denmark
} 
coastline, but a steepening of the coastal profiles outside the tips of the groynes was observed and led to a fear that an uncontrollable coastal erosion could be caused by a series of severe storms, Sørensen et al. (1996), Jacobsen et al (1998). In the 1940-ies it was therefore decided to close the channel and construct sluices and a navigation lock. Subsequently an extensive technical investigation was carried out at the initiative of Professor Lundgren after the publication of Per Bruun's (1954) doctoral thesis. The technical investigation led to the conclusion that the conditions were sustainable without closing the channel, and following this monitoring and management of the protection works have been carried out by the Danish Coastal Authority. The steepening of the profile has continued at a reduced pace and the position of the coastline is maintained by regular nourishment of about $750,000 \mathrm{~m}^{3} / \mathrm{yr}$.

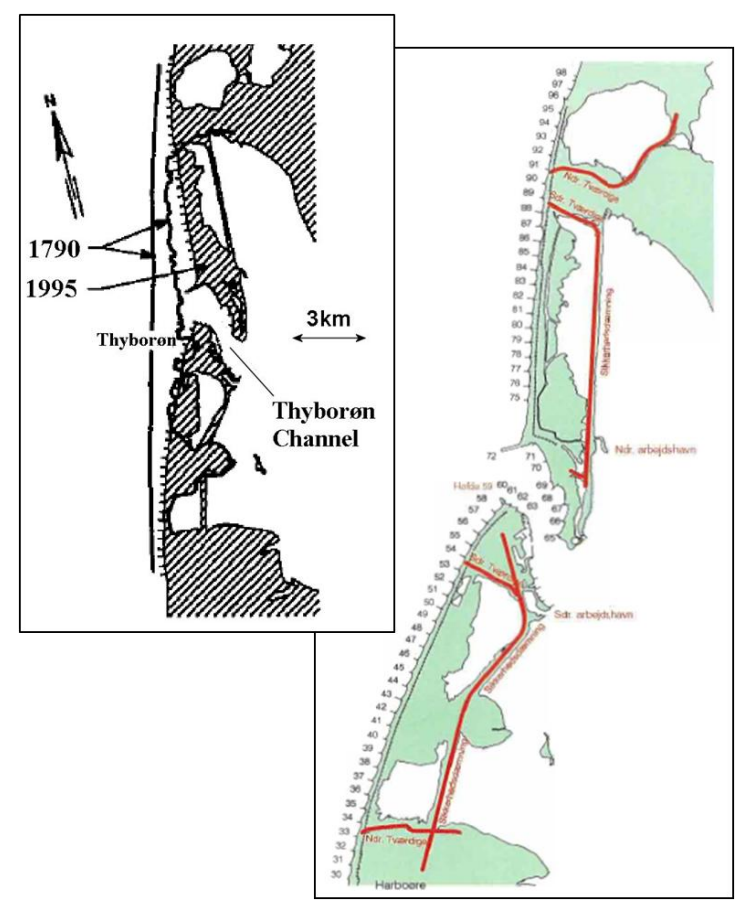

Figure 2. The coastlines before the breach and the present protection works.

\section{EXISTING CONDITIONS}

During the recent years the harbour has experienced increasing problems with respect to wave disturbance and maintenance of the navigation depth of $8 \mathrm{~m}$. The increased wave agitation resulted in more difficult navigation conditions outside the harbour mouth and overtopping of the protective breakwater south of the harbour mouth, see Figure 3. Inside the harbour, the increased wave heights caused critical wave disturbance leading to many occasions of broken moorings. These conditions were not limited to extreme offshore wave conditions but occurred also for moderate offshore waves approaching from northwest.

Sedimentation occurred in the approach corridor just outside the harbour, which resulted in the navigation depth being less than the stipulated $8 \mathrm{~m}$ and instances of vessels touching the bottom, especially during low water and rough weather conditions.

As a remedy the protective breakwater south of the harbour mouth, which had a vertical sheet pile front, was reinforced by a rubble mound slope at the breakwater front. This removed the immediate threat to the structures of the harbour, but it did not solve the difficult navigational and mooring conditions at and in the harbour. 

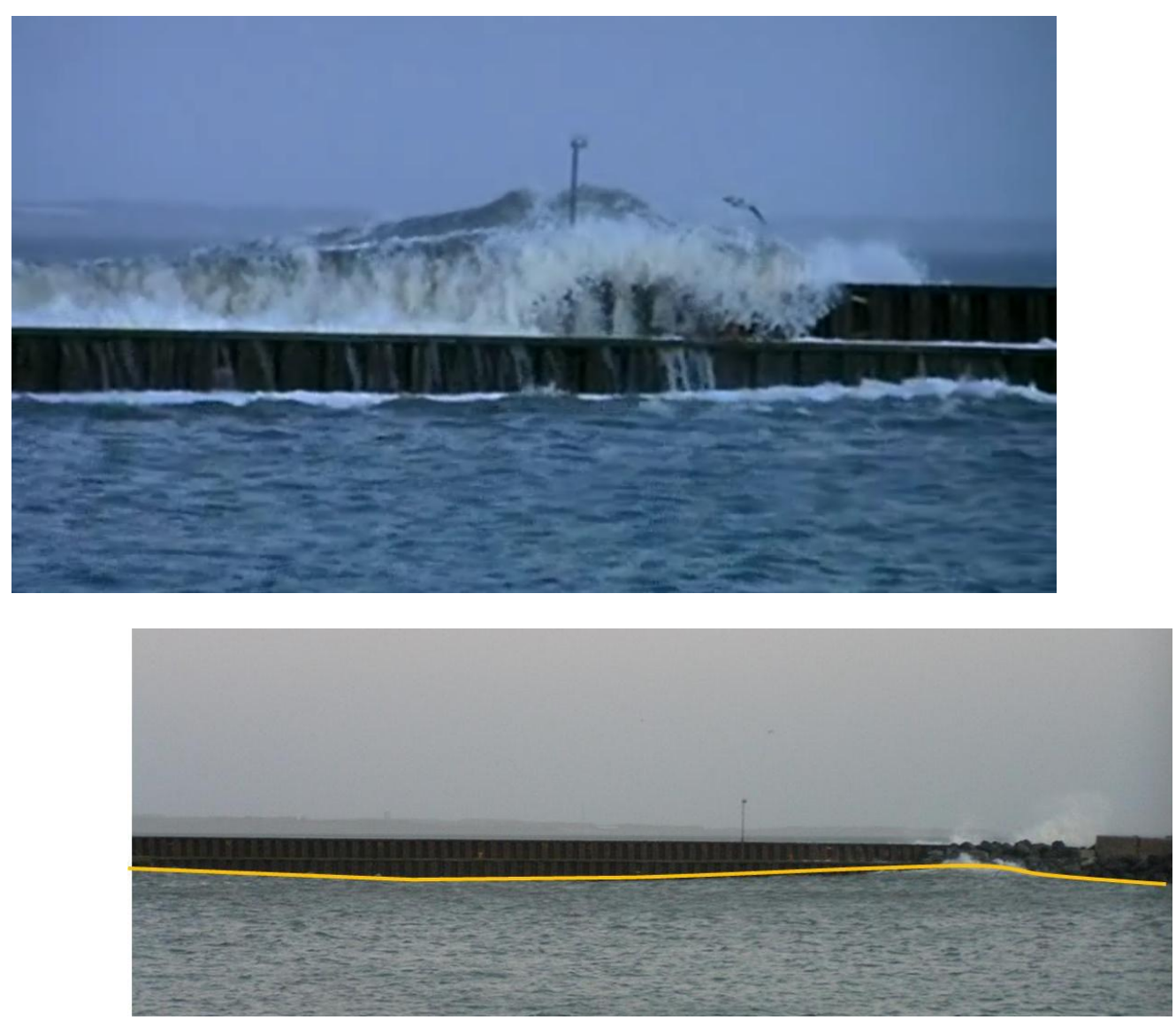

Figure 3. Severe overtopping of the breakwater just south of the harbour entrance (upper figure) and wave disturbance inside the harbour basin.

A study was initiated by the harbour to investigate the reasons for the adverse conditions and to investigate possible solutions: why has the wave conditions changed, and can a remedy be found? What are the reasons for the sedimentation in front of the harbour?

The main elements of the study were: 1) Analysis of available data to investigate the morphological evolution and historic variations in the forcing conditions especially the offshore wave climate. 2) Establishment of calibrated wave models to investigate the wave conditions in the Thyborøn Channel and possible interventions to improve the conditions. 3) Establishment of a calibrated current model and a sediment transport model capable of representing the main transport patterns and the sedimentation process in front of the harbour entrance.

Existing studies (e.g. Brøker et al., 1996, and Kystdirektoratet, 1999) have shown that the littoral transport from the surrounding coasts to the inlet still occurs at rates in the range of $150-400,000 \mathrm{~m}^{3} / \mathrm{yr}$ coming from south and $0-100,000 \mathrm{~m}^{3} / \mathrm{yr}$ coming from north, see Fig.4. The groynes have reduced the natural transport and the coastal erosion to approximately $2 \mathrm{~m} / \mathrm{yr}$. The erosion is balanced by beach nourishment and the position of the coastline is maintained. The sand transport to the inlet from the coast is transported through Thyborøn Channel and deposited on the shoals in the outer part of the fiord, which are accumulating approximately $500,000 \mathrm{~m}^{3} / \mathrm{yr}$ of sand and are increasing in bed level and progressing into the fiord. 


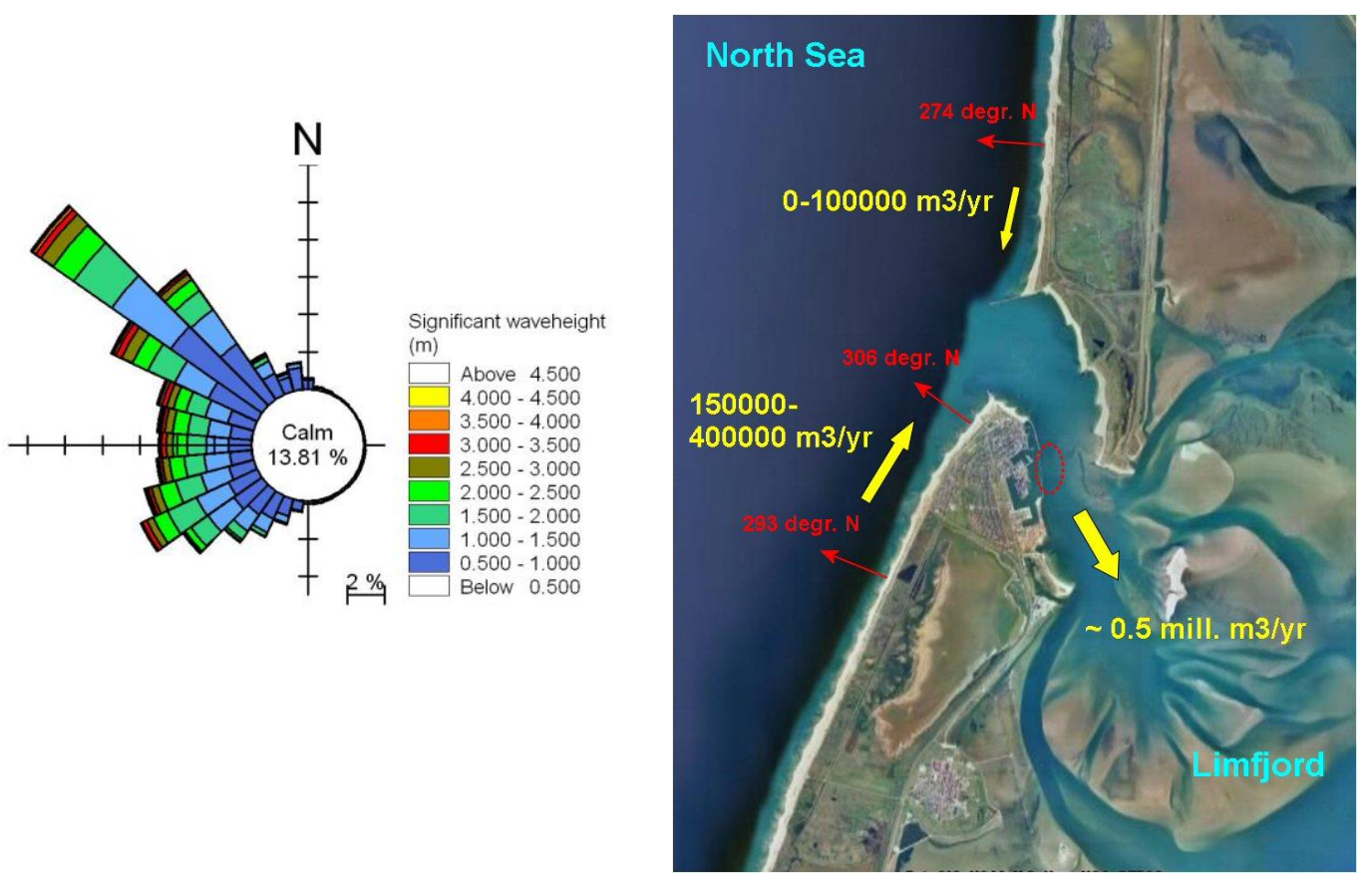

Figure 4. Left: A wave rose describing the offshore wave climate. Right: The overall sediment budget. The approach area in front of the harbour mouth is indicated by the red ellipse.

\section{MORPHOLOGICAL DEVELOPMENT OF CHANNEL}

\section{Morphological Long-term Development}

Detailed surveys of the channel and the areas offshore of the inlet are carried out by the Danish Coastal Authority every five years. The historical bathymetries together with the flow and sediment transport simulations have formed the basis for the analysis of the morphological evolution of the channel over the last 1-2 decades.

The outer part of the channel forming the mouth to the North Sea is relatively shallow with water depths of 7-10 m, see Fig. 5. There is a shoal in the middle of the channel entrance with two possible navigational approaches; one north and one south of the shoal. The preference of one of the approach channels to the other for navigation to and from the harbour depends on the wave and current conditions. The two approaches merge into the main channel. The trend for the outer area with the approach channels has been a gradual increase of the depth, while the position of the approaches varies with time.

The area immediately north of the harbour is a depositional zone with water depth of approximately 5-7 m, where part of the sediment entering from the southern North Sea coast is accumulating (Fig. 6). The extent and water depth at the deposition zone vary in time; however, the overall trend for the sediment balance for the channel is that more sediment leaves it towards the shoals in the fiord than comes in from the sea, leading to an overall trend for erosion in the channel.

The main trend for the main channel is a continued pressure for the channel to shift towards east, away from the harbour, see Fig. 6. This has reversed an earlier trend for deepening outside the harbour entrance, to a critical reduction of the depth from $11 \mathrm{~m}$ to $9 \mathrm{~m}$ between year 2000 and 2007. After 2007, the trend has continued and dredging has been carried out to maintain the guaranteed navigational depth of $8 \mathrm{~m}$. Analysis of the wave conditions has shown that the amount of sediment to be dredged in front of the harbour is positively correlated to the severity of the wave climate. 

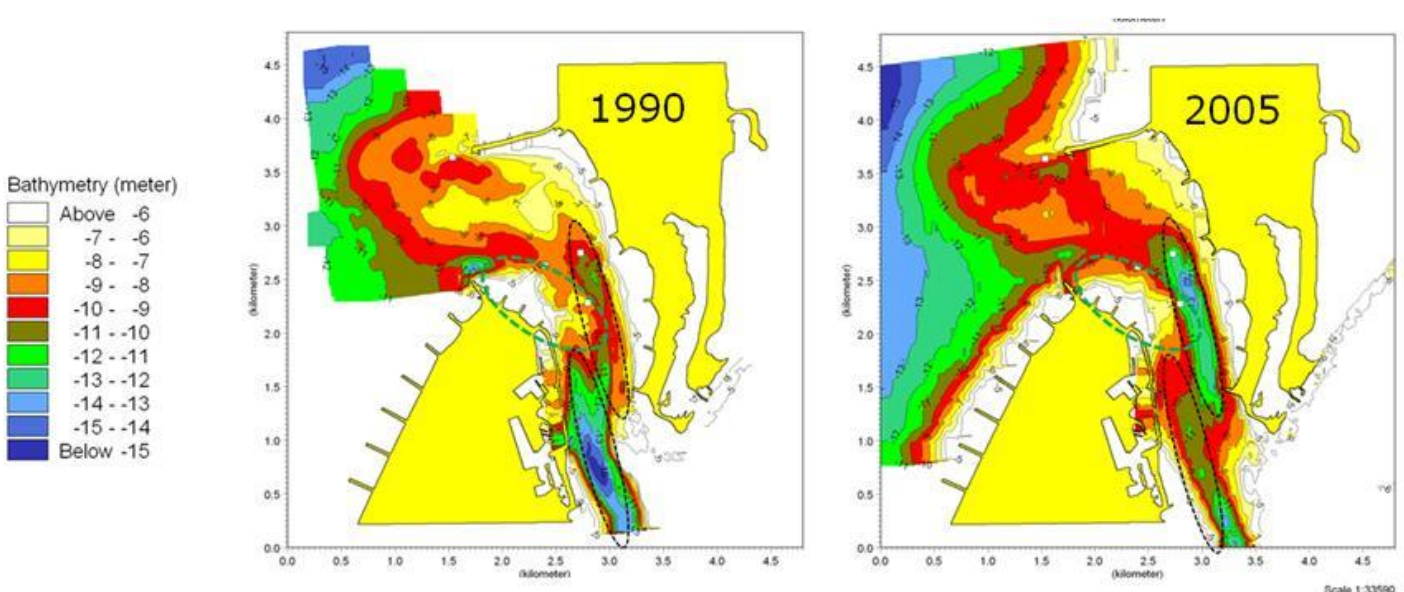

Figure 5. Bathymetries from 1990 and 2005. Note the general lowering of the bed in the outer part of the inlet. The accumulation area north of the harbour is indicated by green ellipse. The deepening of the channel is indicated by the ellipse east of the accumulation area and the area, where water depths reduce, by the ellipse south of the accumulation area.

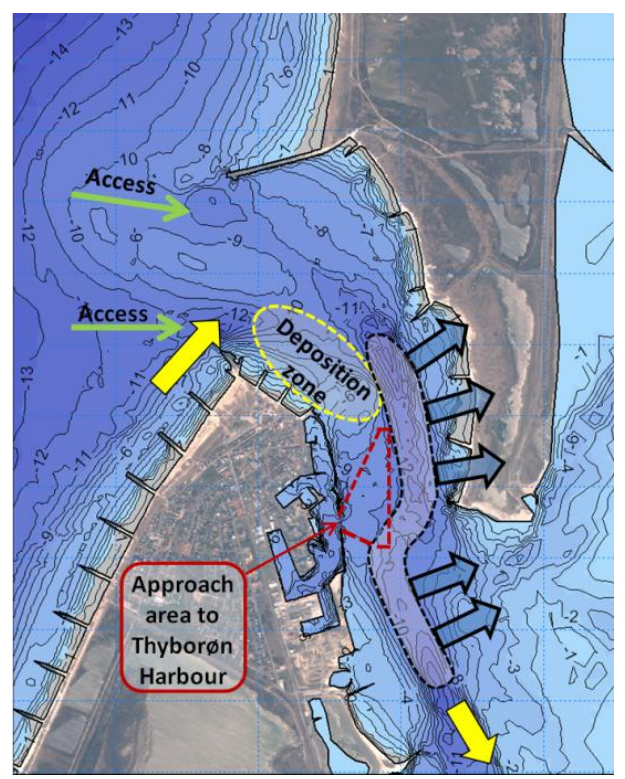

Figure 6. The long-term morphological evolution of the Thyborøn Channel. The two possible access routes from the North Sea are indicated. The main channel tends to be shifted east, as indicated by the blue arrows.

\section{Flow and Sediment Transport}

An understanding of the flow and sediment transport conditions in the channel was obtained through analysis of results from numerical simulations. A flow model was set up with MIKE21-FM HD (hydrodynamics) and calibrated based on ADCP-measurements carried out as part of the study by the Danish Coastal Authority. The model includes meteorological forcings, tides, wave radiation stresses and bottom friction and the model settings were in general based on earlier experience (Brøker et al, 1996). The new measurements carried out in the harbour approach area, approximately $100 \mathrm{~m}$ from the southern breakwater, however, called for a recalibration of the bottom roughness to be able to reproduce the presence and strength of a circulation/eddy cell in front of the harbour entrance during inflow situations, see Fig. 7. Fig. 8 shows a comparison of the measured and modelled current speeds and directions for a period in Nov. 2008.

Due to the circulation cell, the annual net sediment transport direction immediately in front of the harbour entrance is northwards, opposite the main transport direction towards the Limfjord (see Fig. 9). The transport direction in this area is also confirmed by the orientation of bed forms and must be taken into account when planning the dredging operations in the area. The sediment transport field was simulated in MIKE21-FM ST (sediment transport), which applies a deterministic sediment transport 

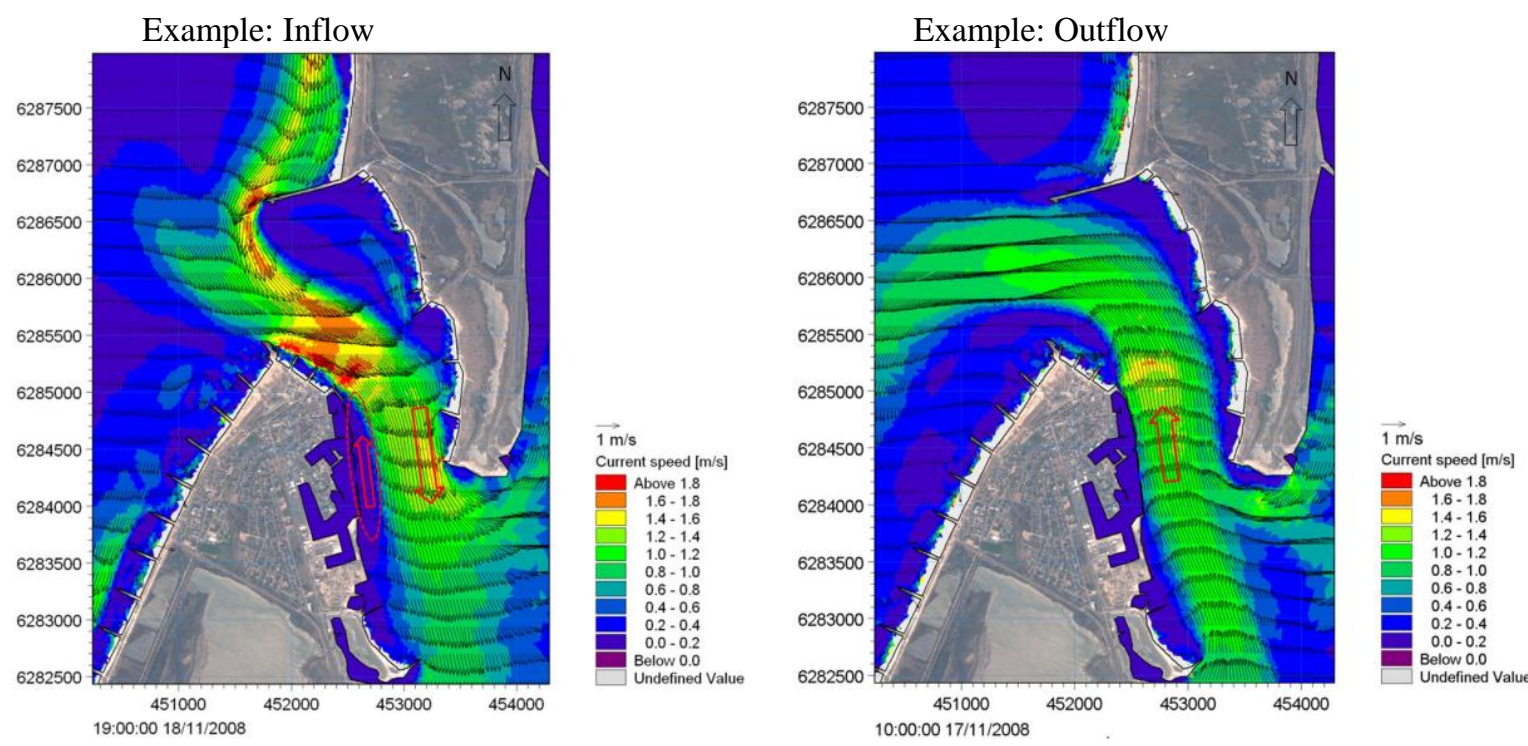

Figure 7. Examples of simulated instantaneous flow fields for an inflow situation (left) and an outflow situation (right), respectively.
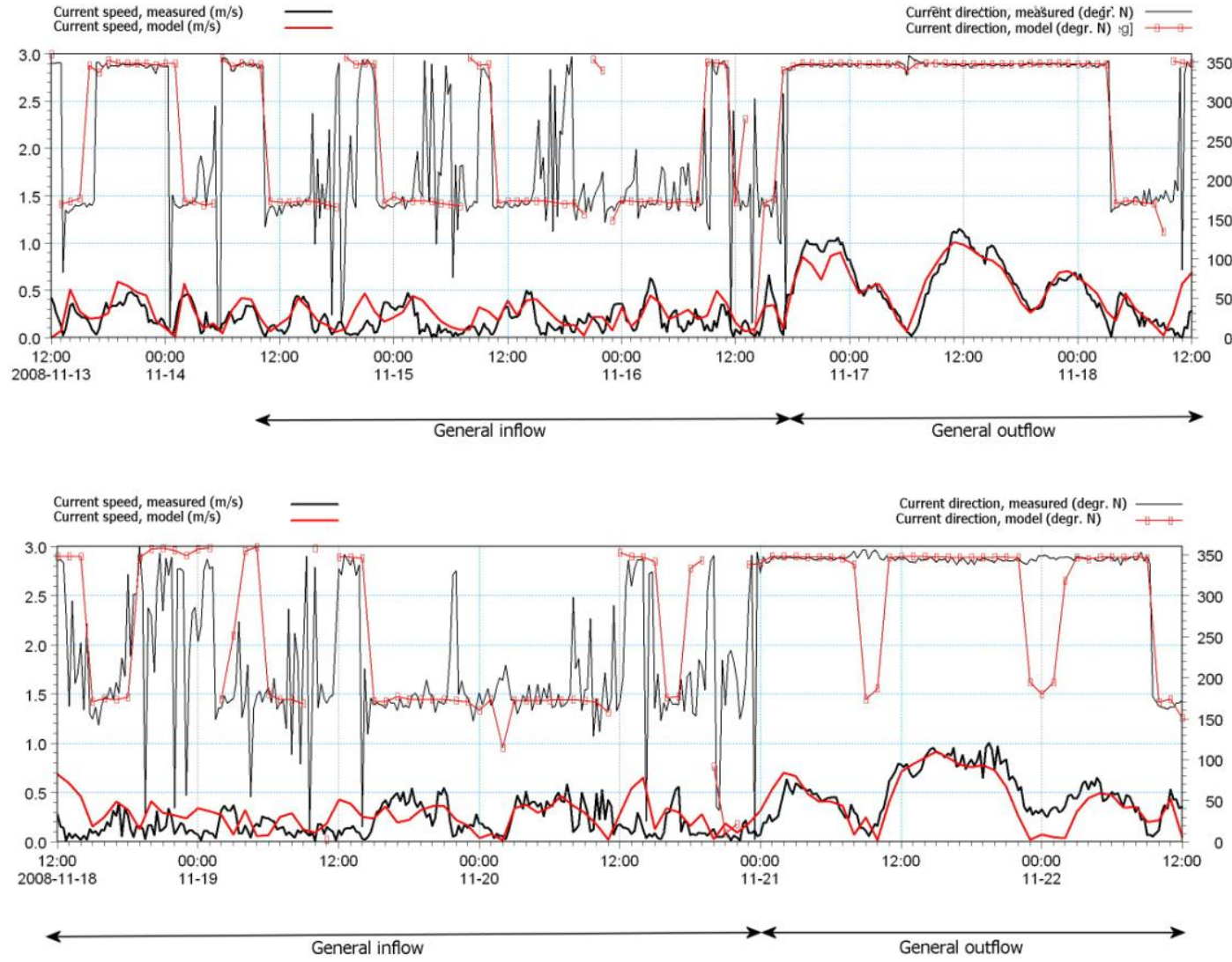

Figure 8. Measured and calculated current speed and direction in front of the southern breakwater, Nov. 2008. Measurements by the Danish Coastal Authority. 
description solved on an intra-wave period time-scale. Annual sediment transport fields were calculated using a compressed time-series approach, based on statistical analysis of measurements of water levels, currents and waves.

Similarly, a consequence of the channel shifting towards east is that the water depth at the groynes at the east side of the channel has increased since 1990. The increased erosional pressure on the groynes opposite the harbour entrance at the northern barrier has led to a retreat of the head of two of the groynes and erosion of the southern part of the northern barrier.

The flow and sediment transport models showed how this reduction in the lengths of the groynes and the barrier caused a weakening in the outflow and in the northwards sediment transport near the harbour entrance, which probably has added to the sedimentation problem in front of the harbour since it may have increased the tendency for the channel to move eastwards.

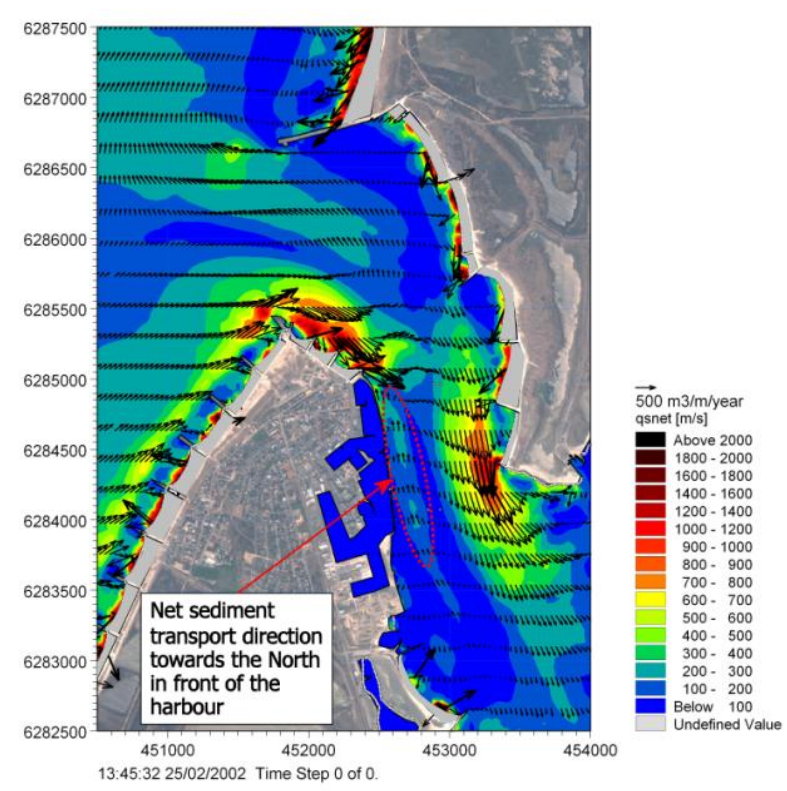

Figure 9. Average annual net sediment transport field for hydrodynamic conditions 1995-2008.

\section{SOLUTION}

\section{Identifying the Causes for Increased Wave Agitation}

Wave measurements and numerical wave transformation modelling were applied, in order to describe the wave conditions causing the problems at the harbour observations.

According to the harbour users the problematic events occur during and shortly after events with strong wind/waves with offshore directions between W and NW. Several events were documented by video and photos. Fig. 3 is showing an example from one of the video documented events with severe overtopping. From the observations, it was assessed that the wave heights were locally amplified $-\mathrm{a}$ socalled Mach Stem effect. This effect occurs when the direction of the incoming wave is close to the direction of the reflective breakwater front.

Over a 4-month period wave measurements were carried out at the harbour entrance. At the same time measurements were carried out outside Thyborøn Channel at $16 \mathrm{~m}$ of water depth. Figure shows the measured wave height offshore and at the harbour for a two-month period. During the measuring period the maximum wave height $\left(\mathrm{H}_{\mathrm{m} 0}\right)$ at the harbour was measured to $2 \mathrm{~m}$. 


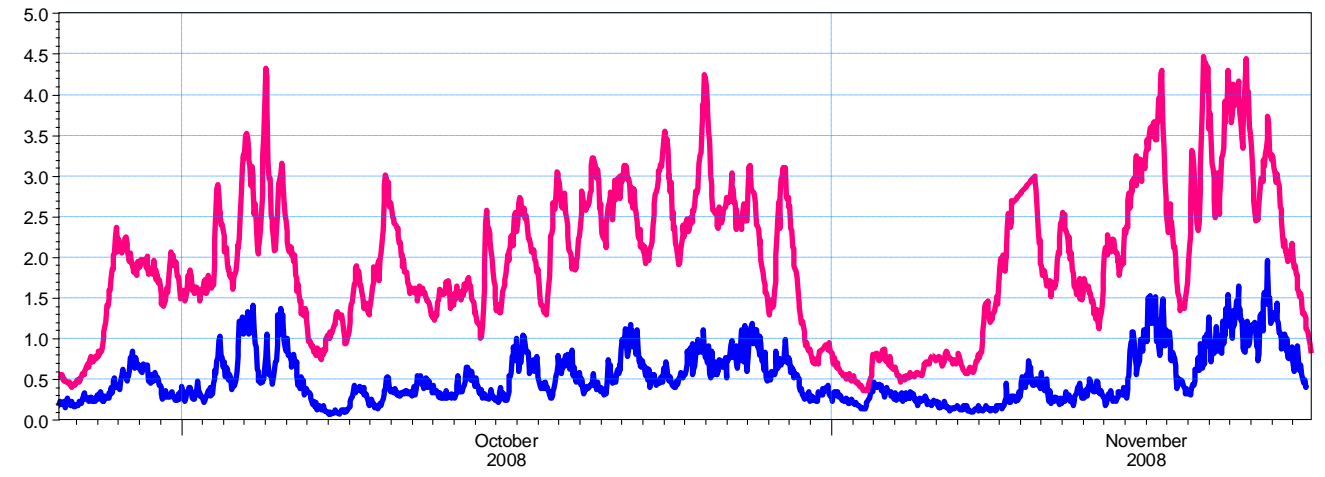

Figure 10. Measured wave heights at the harbour (blue) and offshore (red). $H_{m 0}(m)$.

Fig. 11 shows the wave height at the harbour as function of the offshore wave direction. It is seen that the largest waves at the harbour occur for waves with offshore directions between $290-320^{\circ} \mathrm{N}$. The wave period for the larger waves at the harbour was 8-12 s.

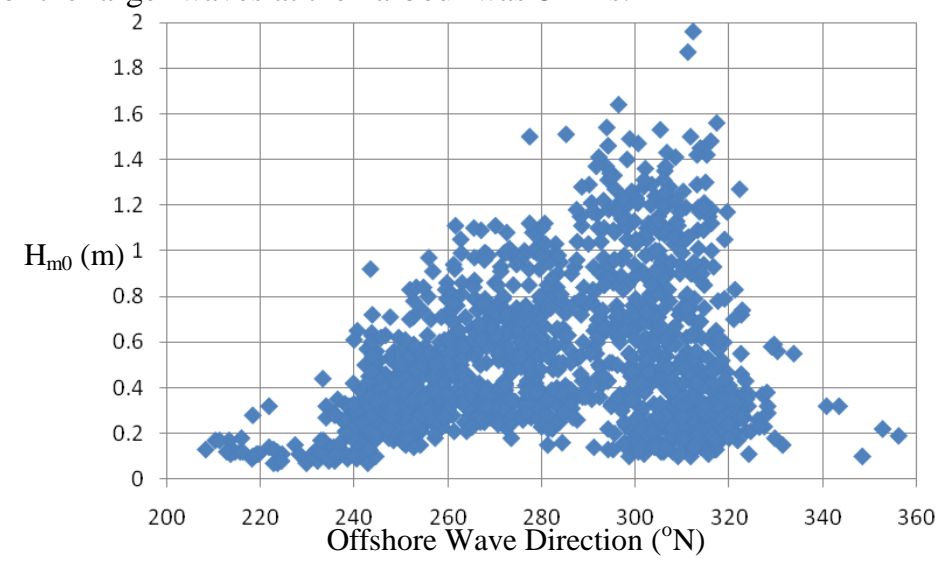

Figure 11. Wave Height, $H_{m 0}(m)$ at the harbour as function of the offshore wave direction.

A number of numerical wave models were established to be able to: 1) Document the wave transformation towards the harbour. 2) Model the wave transformation for historical bathymetry conditions. 3) Investigate solution alternatives.

A wave modelling complex including MIKE21-FM SW, MIKE21 BW and MIKE21 PMS was set up. MIKE21-FM SW, being a spectral wave transformation model, was applied to model the wave transformation over a longer time period and included the effect of the varying water level and current conditions on the wave conditions. This model was primarily applied for the sediment transport modelling. Fig. 12 presents results from the MIKE21-FM SW model, showing the measured respectively the modelled wave height at the harbour. For the modelling the measured offshore wave conditions were applied as boundary conditions.

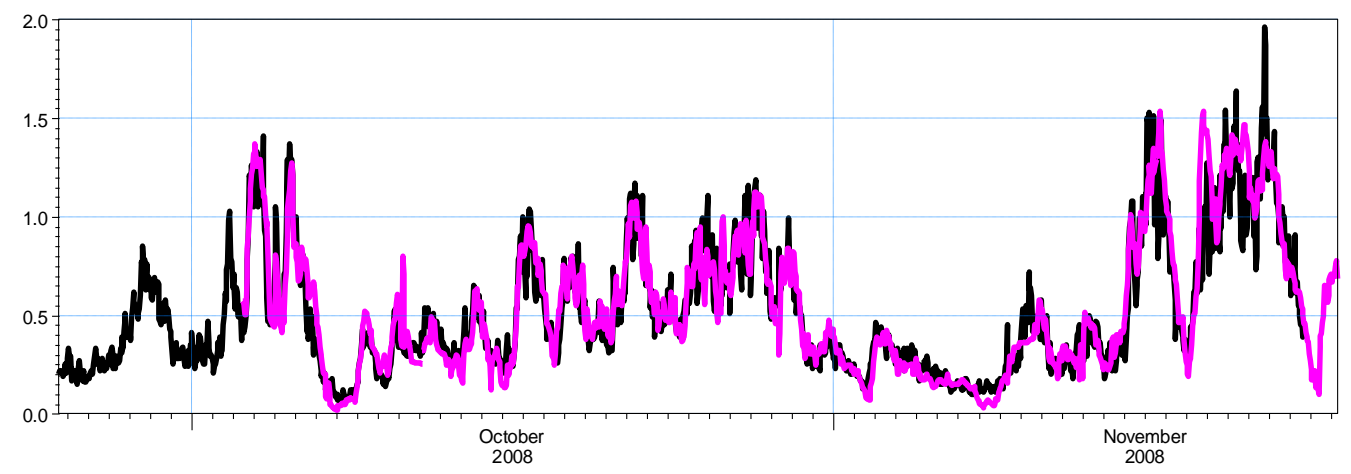

Figure 12. Measured (black) and modelled (pink) wave height $(\mathrm{Hm0})$ at the harbour. Model : MIKE 21 SW. 
MIKE $21 \mathrm{BW}$ is considered the most accurate of the wave transformation models. It reproduces the bathymetry and structures in great detail. The model was applied for selected stationary wave conditions. Fig. 13and Fig 14 show results from a MIKE21 BW simulation for waves from $300^{\circ} \mathrm{N}$ with a wave period of $10 \mathrm{~s}$.

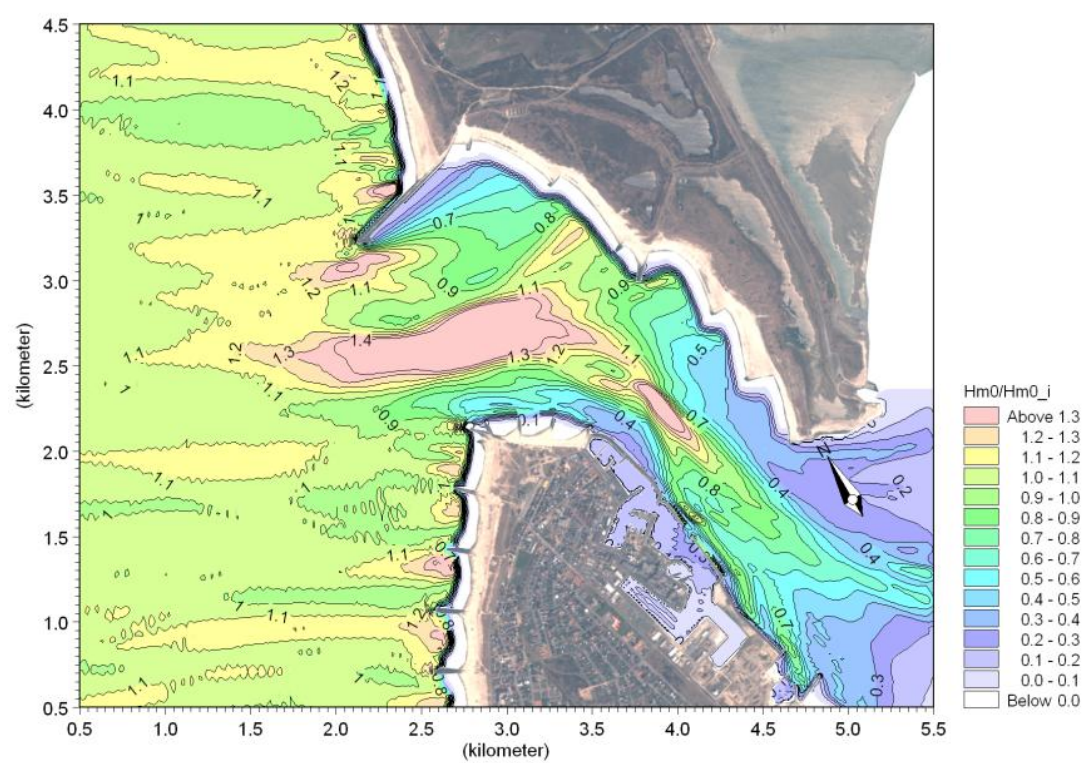

Figure 13. Relative wave heights. Waves from $300^{\circ} \mathrm{N}$, with $T_{p}=10 \mathrm{~s}$.
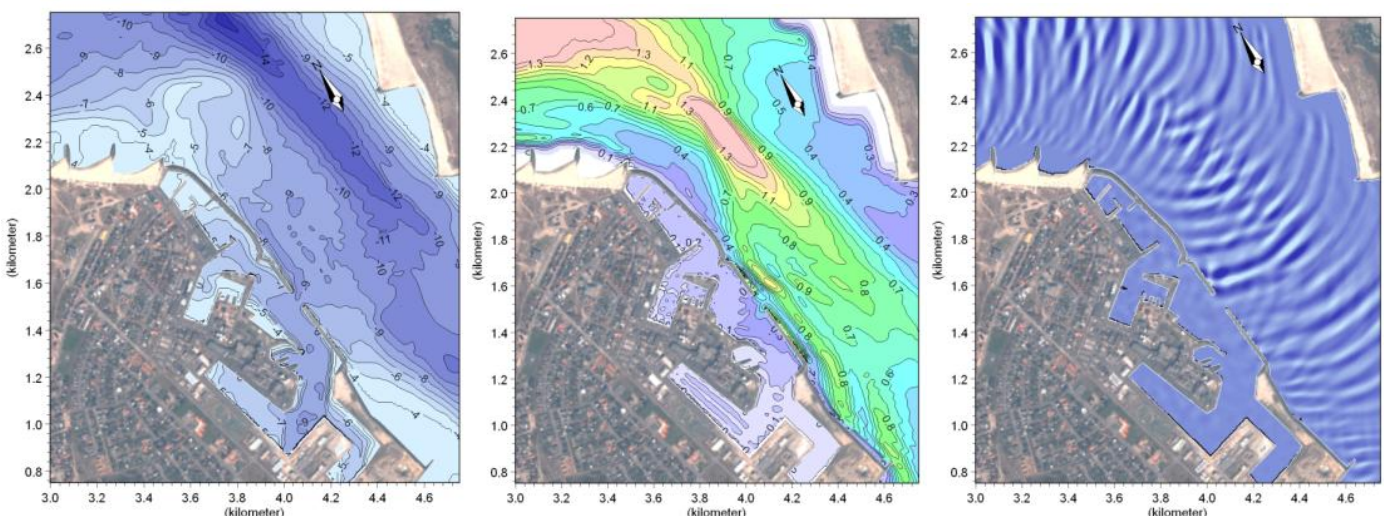

Figure 14. Close-up at harbour, Left: Bathymetry. Centre: $H_{m 0}$, for offshore $H_{m 0}=1$. Right: Snapshot of surface elevations.

It was found that a pronounced focussing of the waves occurs at several locations in the channel. This is mainly due to wave refraction caused by the complex bathymetry. For the wave conditions at the harbour entrance the bathymetry north of the harbour plays an important role as the bathymetry here is very complex with a shoal with minimum depths of $5 \mathrm{~m}$ close to a deep natural channel with depths of $15 \mathrm{~m}$. This focusses the waves and changes the wave direction towards the harbour entrance.

Based on the observations, measurements and numerical modelling it was concluded that the large waves at the harbour occur for offshore wave directions between $290^{\circ} \mathrm{N}$ and $320^{\circ} \mathrm{N}$ with wave periods between 8 and 12s. The waves focus and turn towards the harbour entrance at the northeastern slope of the shallow shoal north of the harbour.

\section{Influence of Changed Bathymetry on the Wave Conditions}

As the problematic wave conditions had developed within a few years before 2008, it was relevant to investigate the wave transformation also for historical bathymetry conditions. Based on historical bathymetry data, two models were set up - one representing the 2008 conditions and one representing the 2004 conditions. In 2004 there were no wave problems at the harbour. 
For the two model bathymetries, wave simulations were carried out modelling the wave conditions documented to represent conditions causing large waves at the harbour. The bathymetries for the two models are shown in Fig 15.
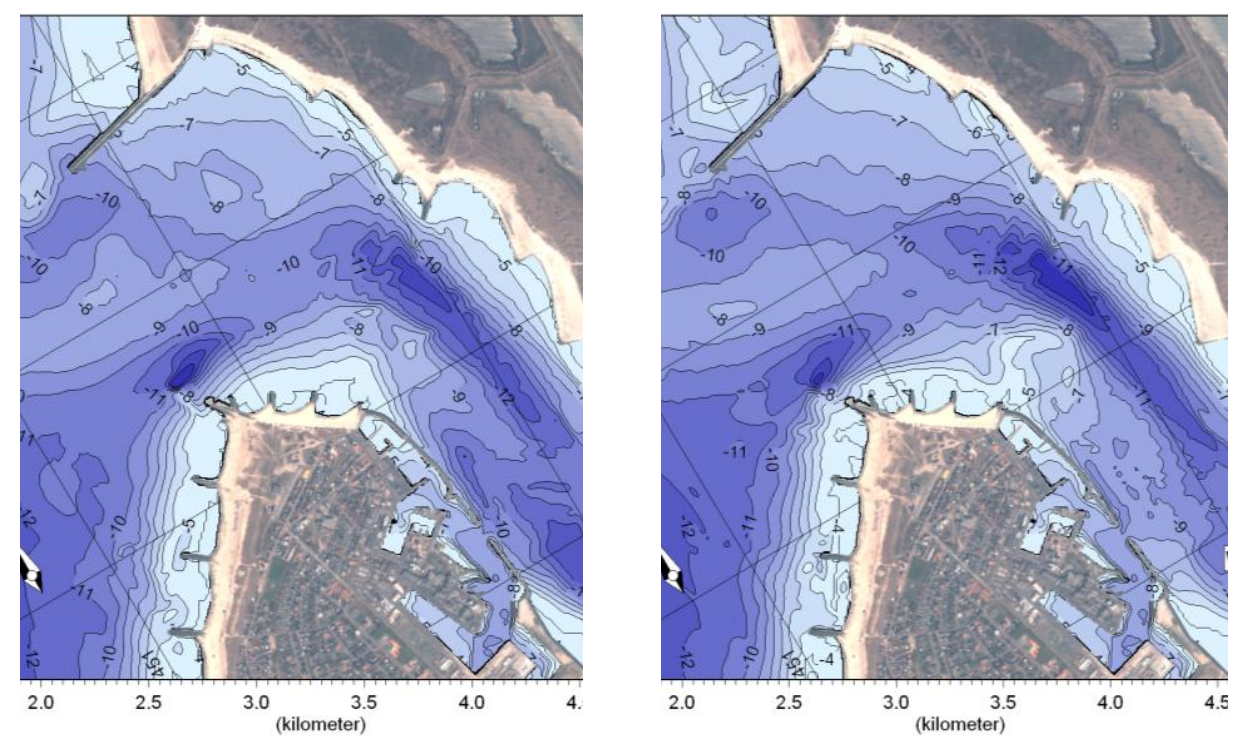

Figure 15. Bathymetries representing the 2004 (left) and 2008 conditions (right).

Examples of simulation results are presented in Fig. 16, showing the relative wave height for waves from $300^{\circ} \mathrm{N}$ and $\mathrm{Tp}=10 \mathrm{ds}$. Examples of instantaneous surface elevations are presented in Fig. 17. The simulations in Fig. 16 and Fig. 17 are made with identical time series for the wave boundary conditions. The two snapshots are taken at the same instant in the simulations and the differences in the wave conditions just outside the harbour mouth are obvious. From the simulations it is clear that bathymetry changes in the period 2004-2008 have caused the problematic wave conditions at the harbour to develop. In general it was found that the wave height at the harbour entrance had more than doubled from 2004 to 2008 for the critical events.
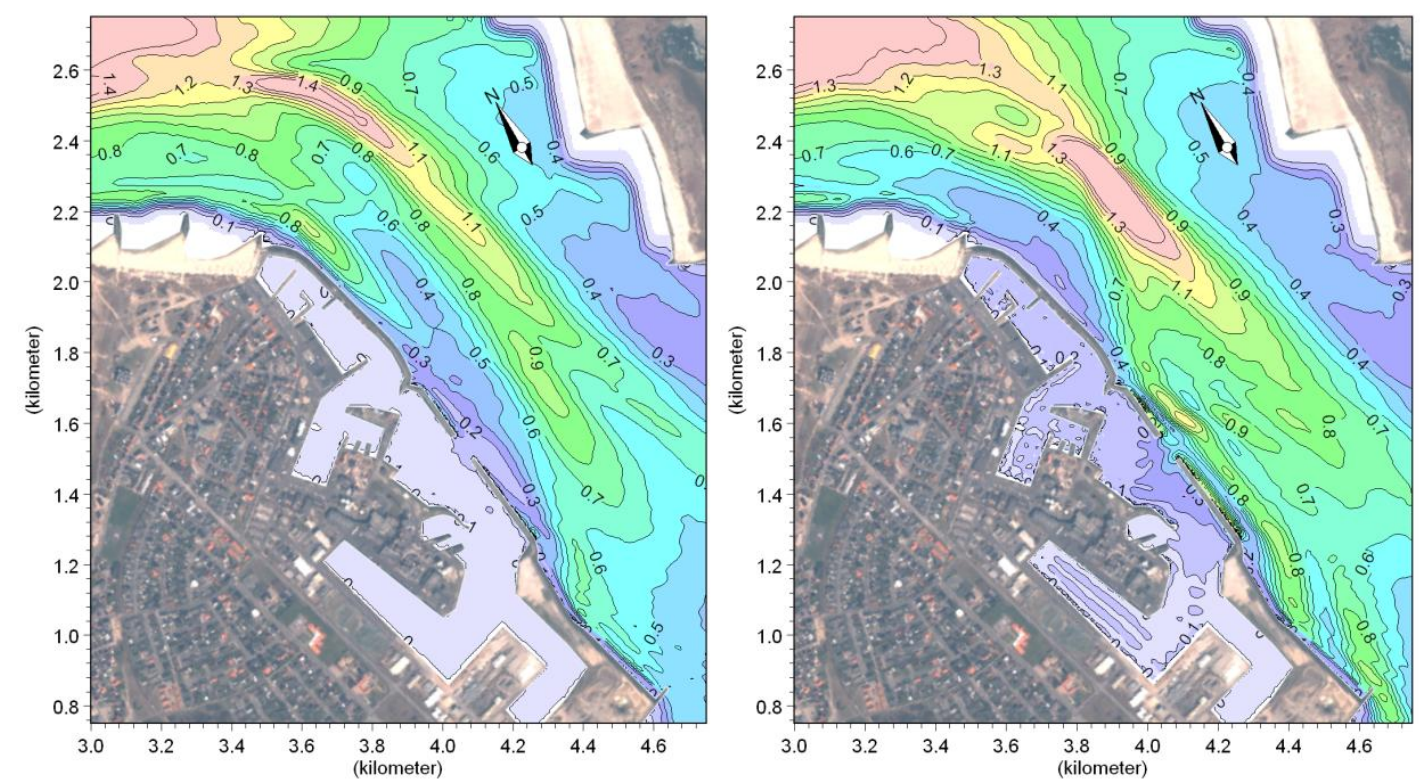

Figure 16. Relative $\mathrm{H}_{\mathrm{m} 0}$. Waves from $300^{\circ} \mathrm{N}$. Left: With 2004 Bathymetry. Right: 2008 conditions. 

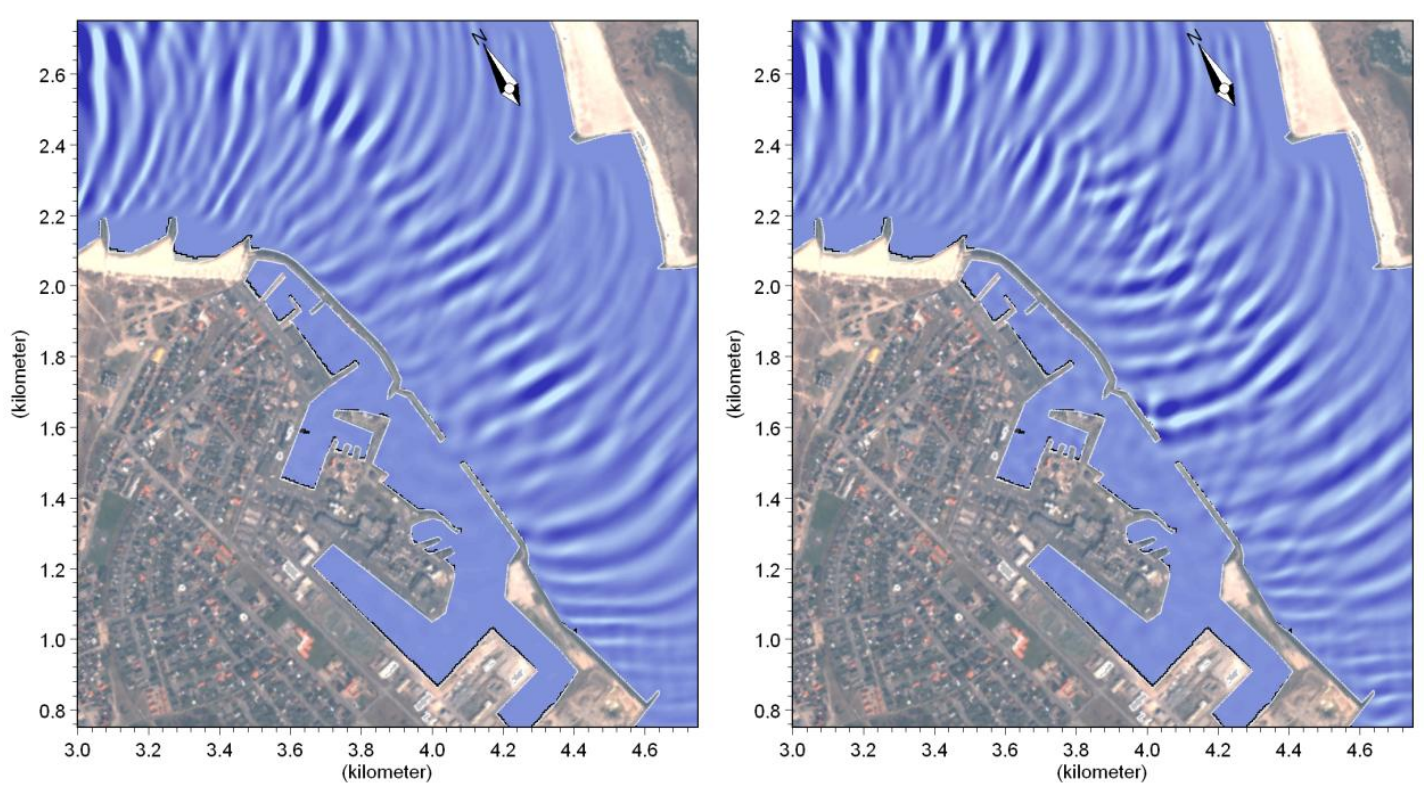

Figure 17. Snapshot of surface elevations. Left: With 2004 Bathymetry. Right: 2008 conditions.

Looking at the bathymetry changes from 2004 to 2008 and the changes in the wave transformation, three main areas were found to be important for the changed wave transformation, marked in Fig. 18. In the orange area it has become deeper from 2004 to 2008 towards land meaning that more wave energy passes this zone instead of refracting towards land. In the green area the slope towards the deep part of the channel has become steeper and more pronounced. This means that the waves refract towards the harbour entrance earlier and stronger than before. In the red area the depths are reduced and the bathymetry has become more equally sloping from the harbour towards the deep parts. This also increases the waves at the harbour. The changes are thus a result of the long-term morphological development of the channel.

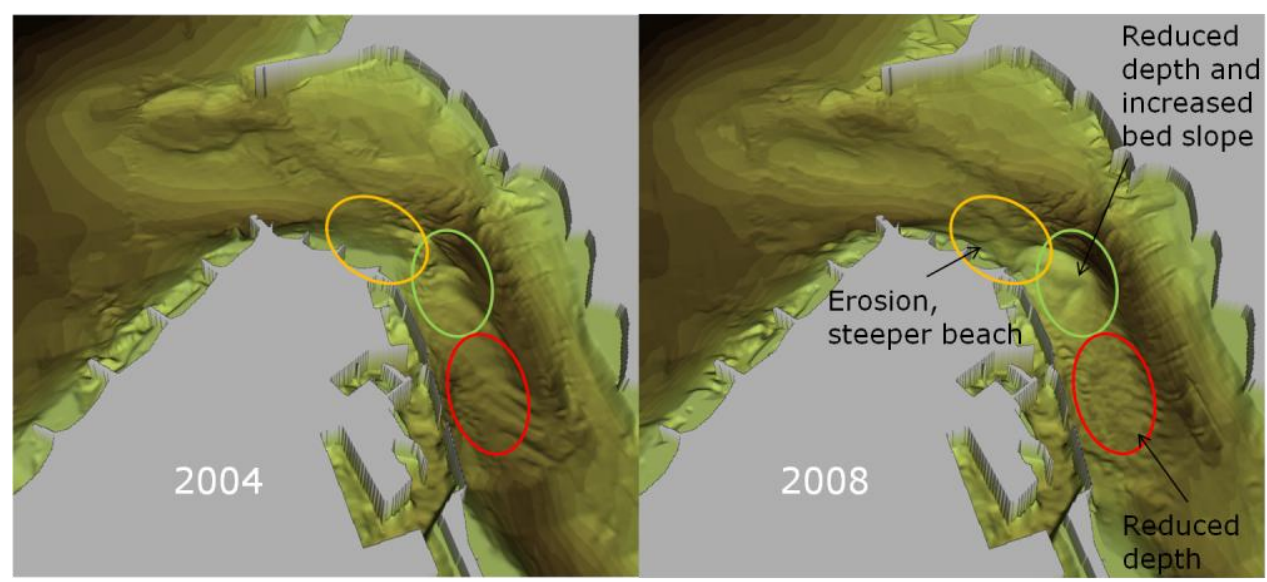

Figure 18. Main areas, where the changes in the bathymetry between 2004 and 2008 are important for the wave conditions at the harbour.

\section{Solution: Impacts on Waves and Sediment Transport of Excavating 400,000 $\mathrm{m}^{3}$}

As the increased waves at the harbour have been caused by bathymetry changes it is logical to consider the possibilities of mitigating the problems by actively modifying the bathymetry in the channel. Re-establishing the 2004-bathymetry completely was, however, not considered feasible. Different alternatives were investigated and it was concluded that a deepening scenario as shown in Fig. 19 was feasible and would eliminate the problematic waves at the harbour. The deepening scenario includes dredging of $400,000 \mathrm{~m}^{3}$ sand at the shoal NW of the harbour to reduce the wave focusing and refraction towards the harbour entrance. 

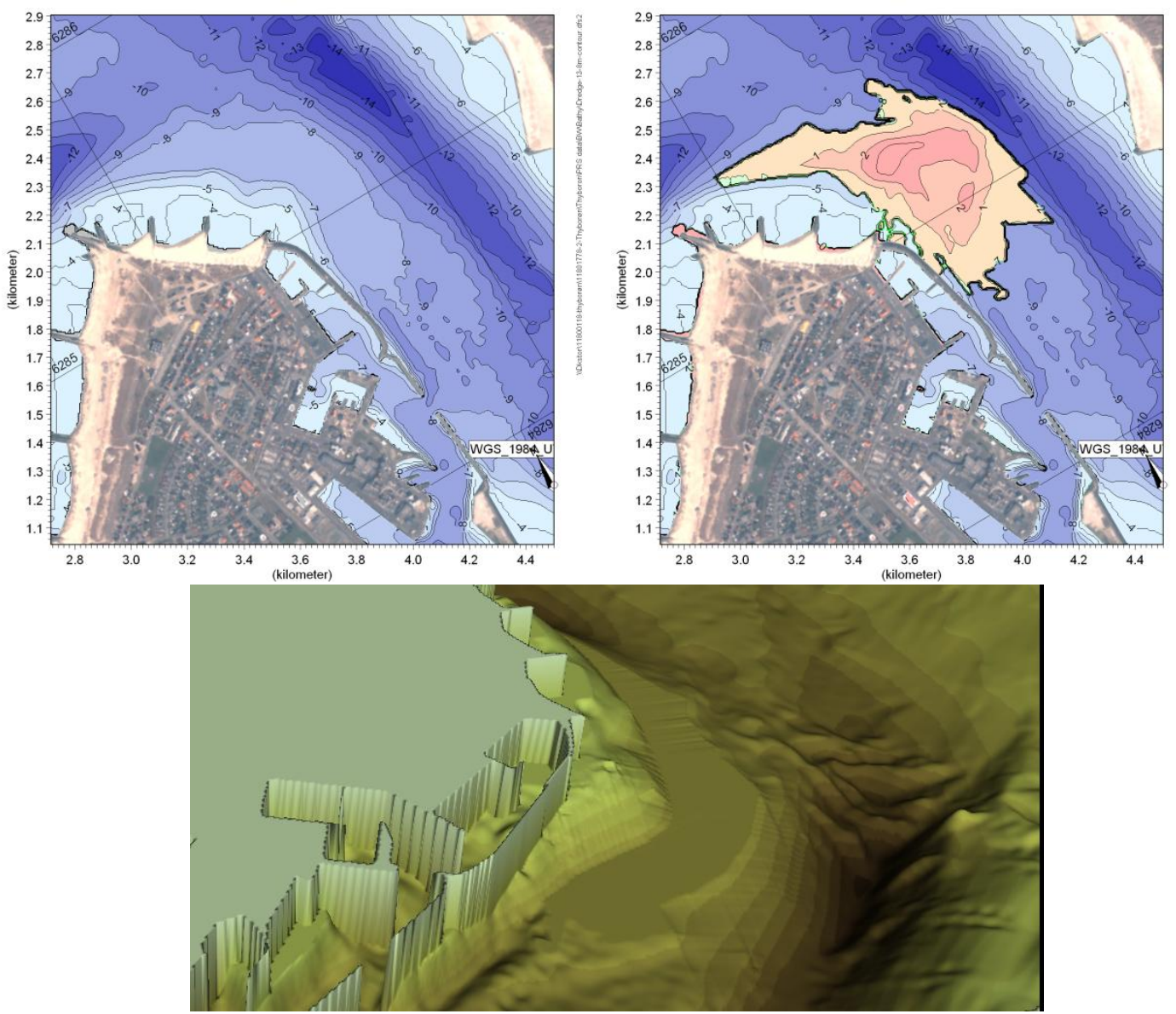

Figure 19. Proposed deepening scenario. Upper left and bottom: Bathymetry after deepening. Upper right: Dredging zone with dredging depths (yellow/orange).

The deepening scenario was optimized through the wave modelling. Figure 20 shows a typical result from the simulation with the deepening scenario, compared with the results for the 2004 and 2008 bathymetry.

With the proposed deepening scenario, the wave heights at the harbour entrance are generally reduced to a level close to the 2004 conditions ie. a reduction in wave height for the critical events by around $50 \%$. Generally, the wave energy entering the channel is not reduced but due to the changed bathymetry the wave energy is spatially redistributed also meaning that other parts of the channel will experience larger waves after the dredging has taken place. This was, however, not considered to be critical by the harbour authorities.

Simulations with the flow and sediment transport models indicate that sedimentation in front of the harbour will not be affected significantly by the excavation. If any, the effect is expected to be a small improvement of the conditions. The sedimentation north of the harbour is expected to continue and the shoal is expected to reform. The solution will therefore have to be maintained; if the improved conditions shall be permanent, regular dredging operations are to be foreseen. 


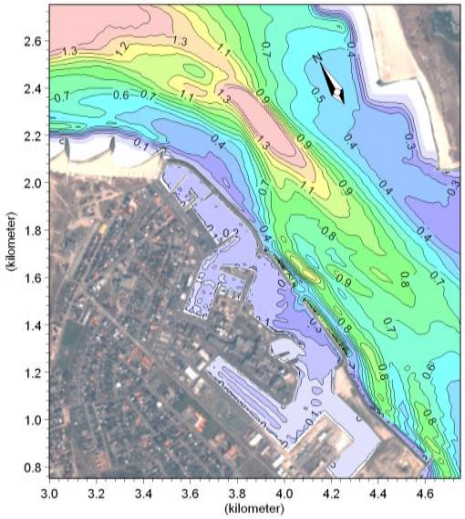

2008

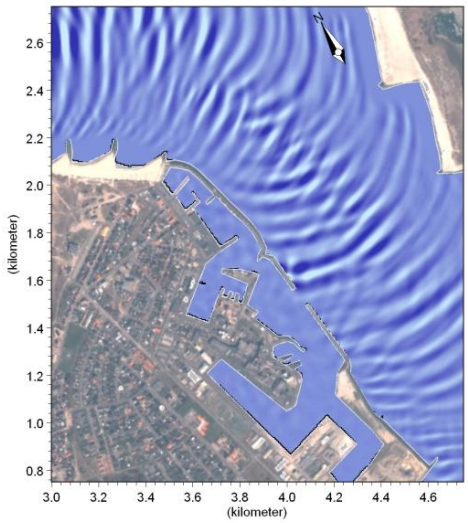

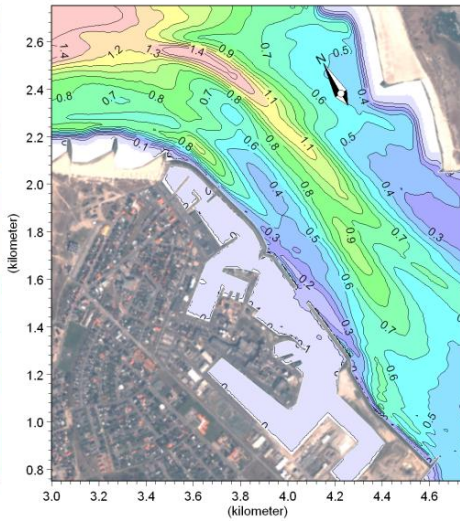

2004

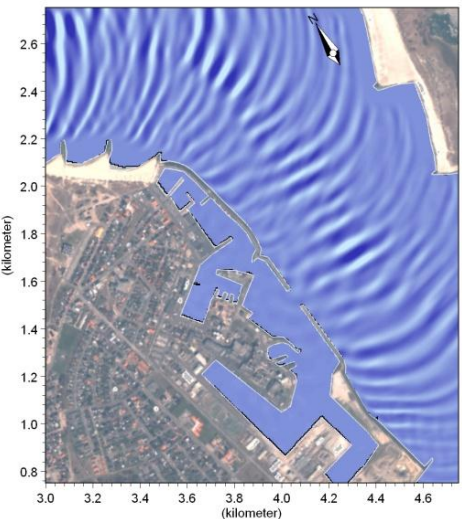

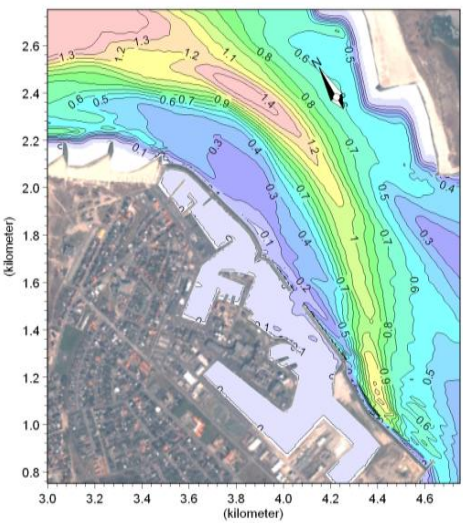

After Deepening

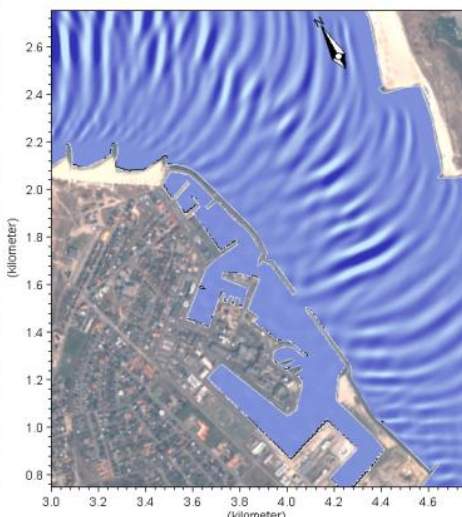

Figure 20. Upper: Relative $H_{m 0}$. Lower: Surface elevation snapshots.

\section{CONCLUDING REMARKS}

The excavation of $400,000 \mathrm{~m}^{3}$ was actually carried out in the Spring of 2010 by the Danish Coastal Authority and has improved the wave conditions in front of the harbour and in the harbour basins significantly. The wave heights south of the harbour entrance may increase since the waves are now deflected more towards the centre of the channel and propagating towards the breakwaters south of the harbour entrance. The sedimentation problem in front of the harbour was shown to remain the same or improve slightly after the excavation.

Regular maintenance (dredging) of the solution must be expected. The excavated sand can be used for beach nourishment on nearby beaches such that the material is recirculated. The solution is therefore a soft and relatively cheap solution with a minimum of impacts to the channel and the Limfjord in comparison with traditional hard structures. In this regard, the solution is in line with the coastal maintenance strategy at the Danish west coast, which is primarily maintained by nourishment to keep the coast and shoreface as natural as possible.

\section{ACKNOWLEDGMENTS}

The Danish Coastal Authority is acknowledged for their assistance to the study by sharing their information on the area and by providing data for the study.

\section{REFERENCES}

Bruun, P. (1954). Coast Stability. Atelier Elektra. Copenhagen.

Brøker,I., Zyserman, J., and Jacobsen, R. (1996). Thyborøn coastal investigation 1995: new lessons from an old coastal problem. Proceedings of $25^{\text {th }}$ International Conference on Coastal Engineering, ASCE, 4703-4716. 
Jacobsen, P.R., Brøker, I., Jensen, J.H., Skou, A. Poulin, S. (1998): Thyborøn Barriers - A mastercase of coastal engineering. Proc. $26^{\text {th }}$ International Conference on Coastal Engineering, ASCE, pp.: 1516-1529.

Kystdirektoratet (1999): Thyborøn - 25 års eftersyn, Hovedrapport. (in Danish) 111pp.

Sørensen, T., Fredsøe, J., Jacobsen, P.R. (1996) History of coastal engineering in Denmark. In: History of Coastal Engineering, Edt.: Kraus, N.C., ASCE, New York, pp.:103-141. 